\title{
Affiliate Contributors to Primary Care for Children
}

\author{
Denise Alexander, Uttara Kurup, Arjun Menon, \\ Michael Mahgerefteh, Austin Warters, Michael Rigby and \\ Mitch Blair
}

\begin{abstract}
There is more to primary care than solely medical and nursing services. Models of Child Health Appraised (MOCHA) explored the role of the professions of pharmacy, dental health and social care as examples of affiliate contributors to primary care in providing health advice and treatment to children and young people. Pharmacies are much used, but their value as a resource for children seems to be insufficiently recognised in most European Union (EU) and European Economic Area (EEA) countries. Advice from a pharmacist is invaluable, particularly because many medicines for children are only available off-label, or not available in the correct dose, access to a pharmacist for simple queries around certain health issues is often easier and quicker than access to a primary care physician or nursing service. Preventive dentistry is available throughout the EU and EEA, but there are few targeted incentives to ensure all children receive the service, and accessibility to dental treatment is variable, particularly for disabled children or those with specific health needs. Social care services are an essential part of health care for many extremely vulnerable children, for example those with complex care needs. Mapping social care services and the interaction with health services is challenging due to their fragmented provision and the variability of access across the EU and EEA. A lack of coherent structure of the health and social care interface requires parents or other family members to navigate complex systems with little assistance. The needs of pharmacy, dentistry and social care are varied and interwoven with needs from each other and from the healthcare system. Yet, because
\end{abstract}

\footnotetext{
(C) European Commission. Published by Emerald Publishing Limited. This chapter is published under the Creative Commons Attribution (CC BY 4.0) licence. Anyone may reproduce, distribute, translate and create derivative works of this chapter (for both commercial and non-commercial purposes), subject to full attribution to the original publication and authors. The full terms of this licence may be seen at http://creativecommons.org/licences/by/4.0/legalcode
} 
this inter-connectivity is not sufficiently recognised in the EU and EEA countries, there is a need for improvement of coordination and with the need for these services to focus more fully on children and young people.

Keywords: Child; adolescent; community pharmacy; dentistry; social care; coordination

\section{Introduction}

This chapter looks at some of the many other professions that provide primary care for children, keeping them well and helping them achieve optimum health. As discussed in Chapters 9 and 16, there is evidence to suggest that the health problems triggering many primary care visits by children and young people could have been treated successfully by other professionals (Gill et al., 2013). Specifically, in Models of Child Health Appraised (MOCHA), we looked at the contribution of, and interface with, community pharmacy, dental health and social care services. Other professions in primary health care, including ophthalmologists, physiotherapists, gynaecologists and psychiatrists, fall outside MOCHA's scope either because of a lack of project capacity or because these services are not generally available in primary care in all of the $30 \mathrm{MOCHA}$ countries; nevertheless, they play an important role. The interface of primary care health services and other professional contributors is not a fixed boundary - but rather, the child's progress between them is fluid. Essential, therefore, in successfully providing these services to the benefit of the child is the need for the primary care health system, and the other systems, to facilitate multidisciplinary communication and working.

\section{The Contribution of Community Pharmacy to Primary Care}

Community pharmacy provides an important primary care service for infants, children and young people and their parents (Alexander \& Blair, 2018; Blair \& Menon, 2018). We know that in many countries, pharmacy is considered an important source of health advice and is used widely before visiting traditional primary care services, and pharmacies have the potential for easier access because of longer opening hours. What has been unknown until now is the extent to which community pharmacy recognises the needs of children and young people, including communication needs, and how it contributes to primary care services as an overarching concept in the different countries of the European Union (EU) and European Economic Area (EEA). MOCHA, therefore, explored how children, young people and their families seek advice about medication, consult over an illness and obtain health advice, including advice about diet, sexual health and so on (Alexander \& Blair, 2018). MOCHA's task was not to appraise pharmacy services themselves, but to investigate their contribution to wider primary care services that can be and are accessed by the children and families of Europe. 


\section{The MOCHA Survey into Pharmacy Use}

Twenty-nine out of the 30 MOCHA country agents (see Chapter 1) returned completed surveys about the accessibility and use of pharmacy by children, young people and their families in their countries and also the quality of service from the pharmacy.

\section{Increasing Access for Children and Young People}

We asked specifically about out-of-hours' accessibility, the presence of private consulting rooms that would allow children to talk to a pharmacist in private, and whether it was seen as usual in the country to visit the pharmacist before seeing a doctor or other health professional.

In most countries, pharmacies provide both dispensing and advice outside of normal business hours. Only a small proportion of countries provide dispensing of medicines $(N=3)$ or over the counter advice only $(N=3)$ out of hours. One country was unable to provide a clear answer to this question, due to the variability of services.

The use of a consulting room in a pharmacy is increasingly viewed as good practice and good for business. Certainly, privacy and confidentiality are very important to children and young people (see also Chapter 3; Alma, Mahtani, Palant, Klůzová Kráčmarová, \& Prinjha, 2017; Blair \& Menon, 2018). If the pharmacy is to be increasingly used as a source of initial primary care advice, prioritising the privacy of the customers raises the standard of care in pharmacies. Sixteen out of the 29 MOCHA countries that responded to this survey question stated that most pharmacies had a consulting room. This is shown in Table 15.1.

Belgium, Germany, Ireland, Norway, Portugal and Romania all stated that pharmacists are legally required to provide separate rooms for confidential consultation. In Portugal, a minimum size of room is also specified in law. In Romania, anecdotally, it was reported that not all pharmacies have the physical space for such a room, despite it being a legal requirement. Austria, Czech Republic, Estonia, France, Iceland, Malta, Netherlands, Spain and the UK have voluntary provision of consulting rooms. In France and Iceland, the provision of a separate space is recommended, and in the UK, it is possible to discuss issues with the pharmacist on the telephone. In many smaller pharmacies,

Table 15.1. Policy for provision of consulting rooms in pharmacies.

\section{Countries with Consulting Rooms Present}

Austria, Belgium, Czech Republic, Estonia, France, Germany, Greece, Iceland, Ireland, Malta, Netherlands, Norway, Portugal, Romania, Spain and the UK

\section{No Consulting Rooms}

Bulgaria, Croatia, Cyprus, Denmark, Finland, Hungary, Italy, Latvia, Lithuania, Luxembourg, Poland, Slovenia and Sweden 
however, it is not possible to include a separate room for private consultations with the pharmacist. In the Czech Republic and Estonia, consulting rooms exist in very few pharmacies, but work is underway to increase that number, and actively encourage the provision of private rooms. Cyprus. Denmark and Finland have no formal requirement for consulting rooms, but they nevertheless exist in some pharmacies. A major barrier to their presence is physical space. In Bulgaria, Greece, Hungary, Italy, Latvia, Lithuania, Poland and Slovenia, there is generally no separate room, but privacy is encouraged by means of a distance between the counter and a queue, or separate counters to consult with a pharmacist.

The majority of countries reported that it was quite usual for the pharmacy to be consulted as a first port of call for health care and advice instead of, or before going to see a physician in primary care. In Spain and Iceland, it was unusual to go to a community pharmacy before visiting a doctor, while conversely in Denmark, Belgium, Bulgaria, Cyprus, Slovenia and the UK, it was becoming increasingly common or it was more common in some areas than others. No country stated that it wasn't possible to visit a pharmacy for initial advice or treatment of general illness.

Some countries had conducted specific surveys about this issue. In Germany, for example, a sample survey of population aged over 15 found that $70 \%$ would consult a pharmacist for advice on medication and that $70 \%$ would judge the pharmacist's advice on medication to be the most important (B.A.H., 2016).

The majority of countries reported that it was normal for a family or a young person to visit the pharmacist as a first port of call particularly for minor ailments such as fever, cough, flu or minor stomach issues before visiting more traditional primary care services. Most country agents said that in their country, people visited the pharmacist in the first instance because it was easier, quicker and, in some countries, cheaper than contacting a physician. One country, Bulgaria, felt it was impossible to answer this question, because of the variation in pharmacy provision in the country, and also the professional competencies of the pharmacist, which might influence the use of the pharmacy.

\section{Quality of Pharmacy Services}

MOCHA's remit was not to appraise pharmacy services, but to look at their role in primary care provision; nevertheless, we aimed to assess how well pharmacy responds to children and young people's needs in particular. We asked about the training of pharmacists specifically in childhood illness and whether any previous national research had been undertaken that described the use of pharmacy by children and young people (Alexander \& Blair, 2018).

We found that the majority of country agents reported that pharmacists in their countries are trained specifically in common childhood illnesses, but the length and type of training vary from country to country. Some reported that it was a compulsory part of pharmaceutical training; in other countries, it is a mandatory post-graduate or continuing professional development requirement. In six countries, no specific training in childhood is needed. This disparity in 


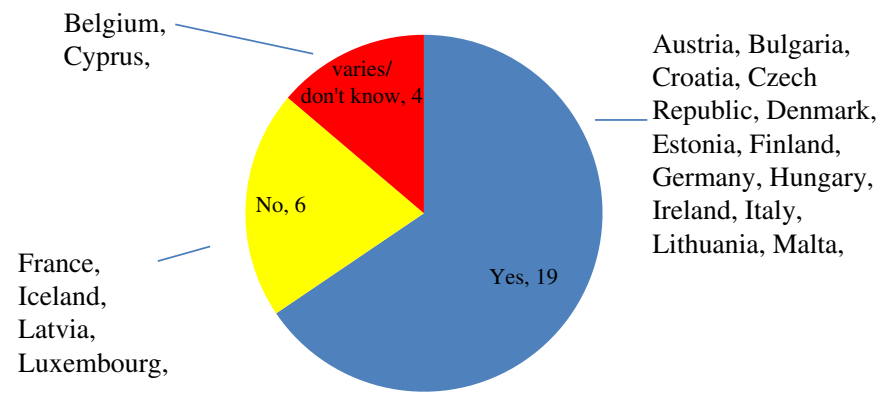

Figure 15.1. Training in the management and treatment of common illnesses in childhood.

child centricity is also reflected in the training of nurses and physicians in childspecific care (see Chapter 13). The breakdown is shown in Figure 15.1.

In most of the countries surveyed, no research had been carried out specifically about young people's use of pharmacy. Children were the focus of research or of community pharmacy initiatives in 11 countries (Czech Republic, Estonia, Finland, Germany, Greece, Hungary, Ireland, Latvia, Romania, Spain and England (as part of the UK)); this included pharmacists being sources of specific health campaigns or health education. For example, the Czech Republic country agent described a campaign initiated in pharmacies to improve the amount of liquid a child drinks as a contribution to fostering good health habits in childhood. In Spain, research focused on the provision of emergency contraception by pharmacists for young women aged older than 15 years. In Estonia, attention was directed towards medicine awareness among children, including its safe use and possible side effects. This initiative was apparently conducted after it was found that only $28 \%$ of the population (all ages) took medicines correctly. In Finland, pharmacy use was the subject of doctoral studies: such as the use of children's medicines (Ylinen, Hämeen-Anttila, Sepponen, Lindblad, \& Ahonen, 2010) and self-medication among children (Siponen, 2014). In Latvia, research took the form of an international survey; the Health Behaviour in School-aged children study reported on teenage use of medication in Latvia in 2013/2014 (Gobina et al., 2014). The Irish Pharmacy Union (2015) and the Pharmaceutical Society of Ireland (2016) identified that children make up around 30\% of pharmacy users (either alone or as part of a family) and young people aged 12-30 made up another $16 \%$ of users - underlining the extent to which pharmacy is used by young people.

A number of countries responded that surveys and research existed into pharmacy use in general, which potentially was of relevance to young people. In Greece, for example, the country reported a survey about people's satisfaction levels with pharmacy, showing that most people were satisfied despite the current economic challenges, and in Portugal, the results of a general survey about pharmacy services by the National Association of Pharmacies were published, but it did not contain specific to parents of young children or adolescents. 
In Poland, the country agent reported that a 2009 survey identified public perception of a pharmacist has having a lack of status as a healthcare professional, even though they are often used as a source of initial advice in the sense of unofficial triage before visiting a doctor. This initial research led to an expert group being set up in Poland to increase the quality of the pharmacists' work and to improve communication with patients (Waszyk-Nowaczyk \& Simon, 2009).

\section{Themes of Pharmacy Use by Children and Young People}

Resulting from this exercise we were able to identify three themes about pharmacy use by children, young people and their families: accessibility, appropriateness and approachability. As described in Chapters 3 and 4, these are of particular importance to children and young people and what we know about optimal primary care services.

\section{Accessibility}

Our questions about access to pharmacy out of hours were important for a number of reasons. The rapid progression of childhood illnesses mean urgent advice is often sought when standard primary care services are unavailable; because young people may want to consult about a health issue without their parents knowing (see also Chapter 11), and because it is quicker, cheaper and easier to talk to a pharmacist about an issue and potentially avoiding the cost or time to see a doctor. In all responding countries, pharmacy has a significant role to play in increasing accessibility in primary care on these terms.

We found differences in the definition of 'out of hours' and our results suggested that it is, in general, much easier to find pharmacies with extended or 24hour service in larger cities than in rural areas. Most countries have systems in place to ensure that pharmacies are accessible to some extent in all parts of a country, but in very rural areas, the distance and fewer opening hours may prove prohibitive to an adolescent seeking advice or treatment.

Another aspect of accessibility is the need to pay out-of-pocket costs. This can be a particularly worrying issue for a child or young person seeking advice, particularly if they are acting independently. Conversely, if a pharmacist provides immediate and free advice, while the medical primary care makes an outof-pocket charge, the community pharmacy is a source of greater accessibility to a child in need.

\section{Appropriateness}

Three separate issues contribute to our knowledge of appropriateness: the extent to which pharmacists are trained in children's illnesses, whether national surveys had been carried out into the use of pharmacy by children and young people and how people, including families and young people, use community pharmacy services in general.

Most pharmacists are trained to recognise and medicate for normal childhood illnesses, although the extent of the training varies between countries. 
In some countries, learning is more ad hoc and undertaken through experience of working in a pharmacy over a period of time. However, the conclusion can be drawn that in those countries where training is compulsory; either as part of general pharmaceutical training or as continuing professional development; the unique needs of children are recognised. Their importance in terms of the population using pharmacies for advice and treatment is also appreciated. Similarly, the absence of surveys about pharmacy use by children and young people in many countries gives a worrying indication of the lack of priority that is given to children. This is particularly acute in the current context of constraints on primary care and economic hardship that is faced by many families across Europe. Such a situation may also reflect a lack of national focus on the role of pharmacy in primary health care for children and young people, despite their unique needs and high use of primary care systems (see also Chapter 6).

The perception of community pharmacy by the general public can be seen as a combination of the results of accessibility and appropriateness of the service. This, to some extent can be seen in those countries that reported it was normal for a young person to visit the pharmacist as a port of call. This could be because there is a general expectation of useful advice and good service from a family, or the fact that primary medical care is not so easily accessible to young people. The majority of countries answered that it was easier to see a pharmacist than it was to book an appointment with a doctor. Within the constraints of this exercise, it is impossible to know, but there is certainly a role for both services, and also warrants serious consideration of greater collaboration or communication between pharmacies and traditional primary care to achieve better coordination of care.

\section{Approachability}

In our survey, the second most popular reason for visiting a pharmacy before medical primary care services was that the pharmacist was more approachable. In addition to this direct question, our question about the presence of separate consulting rooms in a pharmacy addressed an aspect of approachability important to children and young people. This hypothesis was based on the fact that young people value privacy and confidentiality, particularly when seeking advice independently (Alma et al., 2017). Young people stressed that confidentiality and a lack of clarity that their information would remain private was a barrier to primary care for them (see Chapter 4); if young people are not confident that they can discuss issues in private, they are very reluctant to seek help from any professional (Alma et al., 2017). Our survey has highlighted a great deal of variability based on either legal requirements or practical space issues. In many countries, the trend to increasing consulting room facilities has been welcome particularly for adolescents who are seeking a confidential service outside their traditional primary care provider. Despite this, however, it was interesting to note that in five out of the nine countries where it is common to have a separate consulting area in pharmacies, the country agents also said that the pharmacist was approachable and gave health advice. 


\section{The Contribution of Dental Services to Primary Care}

The role of the dentist is also one of great importance as a 'first point of contact' in primary care. Good dental health not only contributes to overall good health, but a dentist may well identify underlying disease as a result of a consultation. In addition to this, dentistry has a strong preventive role, on an individual level in terms of health education and preventive actions, and on a population level, as poor dental health has been used as an indicator for deprivation, low socioeconomic status and even child abuse (Platform for Better Oral Health, 2012) (see also Chapter 5).

We explored how the dental health services address children's primary dental needs and whether there is a close connection between other primary care services. The MOCHA country agents were asked a number of questions about dental services in their countries, particularly focusing on accessibility and availability of dental services, including for children with additional or complex needs.

\section{Accessibility}

In order for dental health services to play a useful role in primary care, they need to be accessible to all. We asked if there is a policy for children to be able to access basic dental care free of charge and if these services were for inspection, and for basic treatment, such as a filling. All countries had free access for inspection purposes; France and Slovakia do not provide free basic treatment to children. There was no data received from Belgium (Table 15.2).

Table 15.2. Is there a policy that all children have access to a dentist free of charge?

\begin{tabular}{|c|c|c|c|}
\hline $\begin{array}{l}\text { Free Service to Children } \\
\text { for Inspection }\end{array}$ & $\begin{array}{c}\text { Free Service to Children } \\
\text { for Basic Treatment } \\
\text { (e.g. Fillings) }\end{array}$ & $\begin{array}{l}\text { No Free } \\
\text { Dental } \\
\text { Service }\end{array}$ & $\begin{array}{c}\text { Free } \\
\text { Inspection } \\
\text { but not } \\
\text { Treatment }\end{array}$ \\
\hline $\begin{array}{l}\text { Austria, Bulgaria, Croatia, } \\
\text { Cyprus, Czech Republic, } \\
\text { Denmark, Estonia, Finland, } \\
\text { France, Germany, Greece, } \\
\text { Hungary, Iceland, Ireland, } \\
\text { Italy (up to age 14), Latvia, } \\
\text { Lithuania, Luxembourg, } \\
\text { Malta, Netherlands, } \\
\text { Norway, Poland, Portugal, } \\
\text { Romania, Slovakia, } \\
\text { Slovenia, Spain, Sweden and } \\
\text { UK }\end{array}$ & $\begin{array}{l}\text { Austria, Bulgaria, } \\
\text { Croatia, Cyprus, Czech } \\
\text { Republic, Denmark, } \\
\text { Estonia, Finland, } \\
\text { Germany, Greece, } \\
\text { Hungary, Iceland, Ireland, } \\
\text { Latvia, Lithuania, } \\
\text { Luxembourg, Malta, } \\
\text { Netherlands, Norway, } \\
\text { Poland, Portugal, } \\
\text { Romania, Slovenia, Spain, } \\
\text { Sweden and UK }\end{array}$ & & $\begin{array}{l}\text { France, } \\
\text { Slovakia }\end{array}$ \\
\hline
\end{tabular}


The majority of countries had a system that ensured every child has a dental examination at set ages. However, in Austria, Bulgaria, Malta, Netherlands, Romania, Poland and the United Kingdom, no specific ages were specified, but in the United Kingdom, for example, guidelines recommend the first dental check-up around the time of the first tooth eruption. Despite no recommendations set at ages, the service is free and children can attend regularly until they reach the age of 18 years. Current evidence has shown this to be a weak incentive, because even in countries where there is a free system, it is known that children of lower socio-economic status do not attend the dentist regularly (Platform for Better Oral Health, 2012). The Estonian country agent reported that many parents in rural areas do not attend the dental service, which seems to reflect this research knowledge. Austria, Cyprus and Luxembourg provide regular dental service through the school system. In Greece and Lithuania, it is compulsory to have a dental check-up before eligibility to preschool. Only Germany, Iceland, Netherlands, Poland and the United Kingdom have no set programme to ensure children have dental examinations at certain ages.

In the countries that do not provide a programme to ensure access to primary dental care, we asked if children with disability or children with a specific clinical risk have facilities available to them to make visiting a dentist easier. In addition to this, country agents that do have set programmes gave further information about access to primary dental care for disabled children or those with a specific clinical risk. These are summarised in Table 15.3. There were no data from Belgium.

We also asked if it was routine for primary care dental practitioners including those working in schools routinely have the facilities to see disabled children in their practices, without referring to specialist hospital services.

In 13 countries (Croatia, Cyprus, Czech Republic, France, Greece, Italy, Lithuania, Luxembourg, Netherlands, Romania, Slovakia and Spain), it was not routine for the facilities to exist in primary care dental practices. Norway answered both 'yes' and 'no' to the question as it was difficult to answer on a nationwide scale. The Czech Republic country agent pointed out that primary care dentistry does not exist in that country in the same way as in other countries, but is carried out in schools via the PLDD doctor (see Chapter 13) who refers to a dentist if necessary; thus, for the Czech Republic, this was an unanswerable question. In Poland, there is no distinction in law between dental services for disabled and non-disabled children. Many of the country agents that stated they did not routinely have such facilities in their countries mentioned that this was the case when a disability warranted any dental examinations or treatment to be carried out under general anaesthetic, and this would need a specialist team in a hospital. Most countries, however, stated that they could provide services to almost all disabled children in primary care, with some exceptions (as would be the case with any condition).

\section{Preventive Care}

An important element in dental primary care is the focus on prevention. Research by the Platform for Better Oral Health (2012) found that children who 
Table 15.3. Access for children with a disability or with a specific clinical risk.

Provision for Children with a Disability or Specific Clinical Risks

Cyprus Children with disabilities or with a specific clinical risk who are unable to receive oral health care on a dental chair are treated under general anaesthesia

Czech Children with a disability which makes access to normal dental Republic services difficult and children with a specific clinical risk are advised about a dentist able to provide such care by their registering PLDD (General Practitioner for children and Adolescents)

Estonia All children (including disabled children) are free to visit any dentist that has signed a contract for financing medical treatment

France These children have the same theoretical access to screening and care as other children. There is a module devoted to children in the course of university training for dentists, but there is nothing specifically dedicated to disability. In hospitals, there are slots (often restricted) for certain pathologies, including mental disabilities

Germany Children with disabilities have the same access to dentistry as those without disability. Many practices are accessible, but sometimes dental care is challenging for the children involved

Italy There is a decree from the Ministry of Health to provide appropriate care for all, but the extent to which this is adhered to in the different regions is unknown

Malta Children with special needs are seen at the Dental Clinic, Mater Dei Hospital. There is a special clinic within Mater Dei Hospital which is dedicated to children with special needs

Netherlands Specialised clinics provide care to these groups as far as these cannot be served in routine dental care. Conditions regarding costs are similar to those for general dental care and in addition covering the special arrangement

Poland All children are treated equally, but disabled young people can have composite light-curing materials for fillings and general anaesthetics before dental procedures if necessary. There is access to highly trained dentists and nurses if necessary

Slovakia Children with a disability and specific clinical risk diseases are treated in university hospitals. In many cases, the problem is in access to hospital due to a long distance. Treatment is done by specialists in cooperation - specialists for paediatric dentistry, anaesthesiologists, dento-alveolar surgeons, haematologists and other medical specialists depend on general diseases 
Table 15.3. (Continued)

Provision for Children with a Disability or Specific Clinical Risks

\begin{tabular}{|c|c|}
\hline Sweden & $\begin{array}{l}\text { Disabled children with special dental concerns because of } \\
\text { behaviour problems as well as an underlying condition or } \\
\text { medication which increases the risk of caries are often cared for in } \\
\text { special programmes by specialist dentists, but this varies between } \\
\text { counties. Secondary preventive programmes exist in several cities } \\
\text { like Stockholm and Malmö }\end{array}$ \\
\hline UK & $\begin{array}{l}\text { - England: The Community Dental Service exists primarily to } \\
\text { serve this purpose but provision is variable and access is not } \\
\text { ensured. There are insufficient Specialists in Paediatric Dentistry } \\
\text { in England. }\end{array}$ \\
\hline
\end{tabular}

- Scotland: Variable across the 14 health board areas of Scotland, and it is up to each health board how it achieves this, but there are facilities available for all children to access dental care, albeit without sufficient specialists.

- NI: Routine screening by the Community Dental Service (CDS) is now only applied to children with special care needs.

-Wales: This is generally provided by the CDS.

brush their teeth twice a day by the age of 12 years are more likely to continue such habits throughout childhood and into adulthood. Regular brushing and other preventive regimes are known to be more common in families of higher socioeconomic status (see Chapter 5), which means that having an established programme of preventive education and check-ups may mean that children from other socio-economic groups are actively encouraged to develop better dental habits.

We asked the country agents to tell us whether programmes exist in their country for oral health promotion and prevention of dental caries and gum disease. Only Hungary, Luxembourg and Romania responded that there was no such programme. In Hungary, several former programmes are no longer active. In Luxembourg, although national programmes do not exist, education in dental health and hygiene is carried out in kindergartens and primary schools by trained medical teams, educators and teachers. The programmes that do exist range from those that cover the entire country but are not nationally produced, rather they are devised and administered by regional health authorities (e.g. in Austria and Greece), a 'dental passport' is given to school-aged children in Croatia and programmes that are mainly administered through the school system, as in Slovenia or Italy.

\section{Economics}

As discussed in Chapter 9, the funding of dental care is important in ensuring its sustainability and accessibility. We asked how preventive dentistry is provided 
for children, giving three choices - a directly employed school dentist (who would in theory be not only very accessible to children in school, but also experienced in children's preventive dental care), a salaried community dentist or a general dental practitioner in their own premises (self-employed).

This is not a simple question to answer in some countries. For example, in Austria, it could be said that none and all of the options were available. Specialised dental physicians visit kindergartens and schools regularly to inspect the children's teeth, and such preventive services are provided by these specialist physicians in their own practices. This is also the case in Luxembourg, where a few dentists exclusively work for school health services, but many others are general dental practitioners who are contracted to work in schools on certain occasions.

In some countries, such as Germany and the United Kingdom, some dentists are working in their own premises, but also employ salaried dentists to work alongside them. In Spain, preventive services are sometimes provided by a salaried community dentist (Madrid Region) or by a general practitioner in their own premises, which is more common in other regions (e.g. Basque Country, or Andalusia Region).

Estonia does not have specialised school dentists, but dentists contract their services to schools as part of the Health Insurance Fund. In France, preventive dentistry is provided by a community dentist, as part of hospital services, or contracted as part of a targeted programme. This is also the case in Poland, where dentists are not employed by the schools, but are financed by the National Health Fund.

We also asked if any of these dental practitioners received additional remuneration for targeted preventive activity, such as fluoride paint, or dental hygiene work, which may show a prioritisation of preventive care, and a means of ensuring that preventive care is available to the child population. The majority of countries said that no such remuneration existed, and in two countries, there were strong regional differences which made it impossible to answer the question accurately (Sweden and the United Kingdom). In the countries that said there was additional remuneration, there were differences in the circumstances in which this could be provided. For example, in Croatia, dentists can contract with the National Insurance Fund to provide additional services such as preventive care and emergency services. In the Czech Republic, a dentist can be reimbursed for preventive care within the rules of the health insurance that covers the patient, and there is a limit as to the number of times a client can be seen in order to claim the costs incurred. Similarly in the Netherlands, dental care is paid for by healthcare packages, and if preventive activities are carried out, such as fluoride paint, they are reimbursed as and when they are provided. In Denmark, private dental practitioners receive extra remuneration for preventive work, as they are subsidised by municipality and by the patient themselves. Danish public dentists, who work in a clinic affiliated with schools, do not receive additional remuneration, as they receive a monthly salary. In Italy, preventive dental services are provided by private dentists. In some cases, they provide preventive services for the local health service, which are reimbursed partly by the national health service and partly by a co-payment from the client; those 
on a low income may be exempt from this co-payment. In Poland, additional remuneration for preventive work is only possible in exceptional circumstances, such as the presence of a particular scheme. In Lithuania, preventive dental care is financially incentivised, as each visit by a child for preventive care is remunerated in addition to normal payment. In Slovenia, payment is given for fluoride gel that is used at schools to routinely prevent caries.

\section{The Interface of Social Care Services with Primary Care}

Social support can be understood as providing assistance to address the everyday or ordinary needs of children so that they can lead full lives and as such are differentiated from health treatment or clinical support. Up until the MOCHA project, there has been very little research to examine the types of social care support in European countries for children with complex healthcare needs in particular (Kielthy, Warters, Brenner, \& McHugh, 2017). The MOCHA project explored the extent to which countries navigate the dynamic and complex interface between social and primary healthcare services. This is discussed fully in (Kielthy et al., 2017).

Social care services are very closely aligned to healthcare services in a conceptual and a practical sense. Without good social care, children cannot live optimally healthy lives and as such, it is an essential part of primary care in its broadest sense. In the MOCHA project, the interface of social care services with primary care services was investigated by researching the experiences of a particularly vulnerable population group of children, those with complex care needs (see Chapter 10) as a tracer for all children who may need social care services for a variety of reasons. The United Nations Convention on the Rights of the Child (see also Chapters 4 and 17) states that all children have the right to additional support they need it, in order to allow them to live full lives. As such, they have the same right to a warm family environment, go to school, make friends and take part in leisure activities as do other children. Some children require the support of social care services to fulfil this right. In terms of the organisation and provision of services, some are universal, and some are targeted at children and young people who are in high-risk groups. These types of social services can vary, even within a country. In universal services, all families are eligible for support, whereas in targeted services, only those with the greatest need or most limited means are eligible. In some countries, such as the Nordic countries of Europe, a cascade model operates: universal services that encompass a preventive approach are available to all families, and more targeted, specialised and tailored support is also available to families and children with complex care needs (Lara Montero, van Duijn, Zonneveld, Minkman, \& Nies, 2016). This is considered to be good practice, but it must be noted that there is an absence of evidence to prove that this improves the outcomes for children with complex care needs, as outcome data are difficult to define, and data are not available that can be compared across different systems (see also Chapters 7 and 8). 
In the case of children with complex care needs, it can be difficult, or even impossible to disentangle the social care needs from healthcare needs, which is an extreme manifestation of the multifaceted relationship social care needs and healthcare needs may have in any child's life. Healthcare needs are so much a part of their everyday lives that dividing such needs into categories of 'health' and 'social care' is untenable (Marchant, Lefevre, Jones, \& Luckock, 2007).

In addition to social care that provides for child welfare, social care also encompasses the safeguarding of children from abuse or neglect (see also Chapter 17). The Fundamental Rights Agency (European Union Agency for Fundamental Rights, 2015a) states that there are significant inadequacies in child protection systems in the EU member states, which often fail children with complex needs from abuse and violence (2015), which has also been reflected in the MOCHA findings (see Chapter 17). The vulnerability of children to being abused because of their dependency on adults is an important factor in ensuring a seamless interface with social care services to produce good health and well-being outcomes for the child. This has also been reflected in the MOCHA findings. We asked about procedures and policy for child safeguarding for a child with complex care needs and how these could be accessed. The MOCHA country agents responded to a questionnaire, which was designed to provide an understanding of the national context in which social care services are provided, and how they integrate with primary social care services. The questionnaire drew upon case studies and vignettes already developed in the MOCHA project (see Chapter 10, and Kielthy et al., 2017) and adapted them to enable an exploration of social care needs. The focus was on care for an individual with complex care needs, by emphasising the policy and legislative framework of social care in that country. The questionnaire responses allowed us to map social care services in the EU and EEA countries and how these link with primary healthcare services in the community. In addition, it provided us with the means to examine the interface between primary health care and child protection, recognising the specific roles that differentiate the need of social care to enable an 'ordinary life' for a child with additional needs, and the need to protect a child from an abusive environment. Specifically, we looked at social care in terms of whether it has a legal basis, the extent to which social care and primary healthcare services are integrated, the way in which social care services is implemented, and the level of participation in and costs of social services.

\section{Legal Basis for Social Care}

We found that all countries have a legal framework for social care, and a main law for the provision of social care services was present in most countries. In 13 countries, special entitlements were available for children with complex care needs, and these were included in social care legislation. Only $35 \%$ of responding countries had a central national authority to coordinate social care. Table 15.4 gives further information.

All countries reported they had a child protection framework, although the Fundamental Rights Agency (European Union Agency for Fundamental Rights, 2015b) reports that a main law for child protection is present in only 
Table 15.4. Legal entitlement to social care for children with complex care needs in European countries.

\begin{tabular}{|c|c|c|c|c|c|c|c|c|}
\hline & $\begin{array}{l}\text { Social Care } \\
\text { Legislation }\end{array}$ & $\begin{array}{c}\text { Special } \\
\text { Provision for } \\
\text { Children with } \\
\text { Complex Care } \\
\text { Needs within } \\
\text { Social Care } \\
\text { Legislation }\end{array}$ & $\begin{array}{l}\text { Measure to Promote the } \\
\text { Welfare of Children with } \\
\text { Complex Care Needs } \\
\text { within Child Protection } \\
\text { Legislation }\end{array}$ & $\begin{array}{c}\text { Financial } \\
\text { Entitlement } \\
\text { in Social } \\
\text { Care Legal } \\
\text { Framework }\end{array}$ & $\begin{array}{c}\text { Home Help OR } \\
\text { Personal Care } \\
\text { Entitlement in } \\
\text { Social Care } \\
\text { Legal } \\
\text { Framework } \\
\text { (HH) (PC) }\end{array}$ & $\begin{array}{c}\text { Family } \\
\text { Support } \\
\text { Entitlement } \\
\text { in Social } \\
\text { Care Legal } \\
\text { Framework }\end{array}$ & $\begin{array}{c}\text { Educational } \\
\text { Entitlement } \\
\text { in Social } \\
\text { Care Legal } \\
\text { Framework }\end{array}$ & $\begin{array}{c}\text { Psychosocial } \\
\text { Entitlement } \\
\text { in Social } \\
\text { Care Legal } \\
\text { Framework }\end{array}$ \\
\hline Austria & $\begin{array}{l}\text { Yes } \\
(\text { Federal })^{\mathrm{ab}}\end{array}$ & $\mathrm{Yes}^{\mathrm{ab}}$ & $\mathrm{No}^{\mathrm{a}}$ & $\mathrm{No}^{\mathrm{a}}$ & Yes $(\mathrm{HH})^{\mathrm{a}}$ & $\mathrm{Yes}^{\mathrm{a}}$ & $\mathrm{No}^{\mathrm{a}}$ & Yes $^{\mathrm{a}}$ \\
\hline Croatia & $\mathrm{Yes}^{\mathrm{ab}}$ & $\mathrm{Yes}^{\mathrm{ab}}$ & $\mathrm{No}^{\mathrm{a}}$ & $\mathrm{Yes}^{\mathrm{a}}$ & Yes $(\mathrm{HH})^{\mathrm{a}}$ & $\mathrm{Yes}^{\mathrm{a}}$ & $\mathrm{Yes}^{\mathrm{a}}$ & Yes $^{\mathrm{a}}$ \\
\hline Cyprus & $\begin{array}{l}\text { Yes (across } \\
\text { different } \\
\text { laws) }\end{array}$ & Other $^{a b}$ & $\mathrm{No}^{\mathrm{a}}$ & $\begin{array}{l}\text { Not } \\
\text { applicable }\end{array}$ & Not applicable & $\begin{array}{l}\text { Not } \\
\text { applicable }\end{array}$ & $\begin{array}{l}\text { Not } \\
\text { applicable }\end{array}$ & $\begin{array}{l}\text { Not } \\
\text { applicable }\end{array}$ \\
\hline $\begin{array}{l}\text { Czech } \\
\text { Republic }\end{array}$ & Yes $^{a b}$ & Yes $^{a b}$ & $\begin{array}{l}\text { Other (recommendation } \\
\text { applicable to children } \\
\text { with physical disabilities) }\end{array}$ & Yes $^{\mathrm{ab}}$ & Yes $(\mathrm{HH})^{\mathrm{ab}}$ & Yes $^{a b}$ & Yes $^{a b}$ & Yes $^{a b}$ \\
\hline Estonia & Yes $^{a b}$ & Yes $^{a b}$ & Yes $^{a b}$ & Yes $^{a}$ & $\mathrm{No}^{\mathrm{a}}$ & $\mathrm{No}^{\mathrm{a}}$ & $\mathrm{No}^{\mathrm{a}}$ & $\mathrm{No}^{\mathrm{a}}$ \\
\hline Finland & Yes $^{a b}$ & $\mathrm{No}^{\mathrm{ab}}$ & No ${ }^{a b}$ & $\begin{array}{l}\text { Not } \\
\text { applicable }\end{array}$ & Not applicable & $\begin{array}{l}\text { Not } \\
\text { applicable }\end{array}$ & $\begin{array}{l}\text { Not } \\
\text { applicable }\end{array}$ & $\begin{array}{l}\text { Not } \\
\text { applicable }\end{array}$ \\
\hline Germany & $\mathrm{Yes}^{\mathrm{ab}}$ & $\mathrm{Yes}^{\mathrm{ab}}$ & $\mathrm{No}^{\mathrm{a}}$ & $\mathrm{No}^{\mathrm{ab}}$ & Yes $(\mathrm{HH})^{\mathrm{ab}}$ & $\mathrm{No}^{\mathrm{ab}}$ & $\mathrm{Yes}^{\mathrm{ab}}$ & $\mathrm{Yes}^{\mathrm{ab}}$ \\
\hline Greece & $\mathrm{Yes}^{\mathrm{ab}}$ & $\mathrm{No}^{\mathrm{ab}}$ & $\mathrm{No}^{\mathrm{a}}$ & $\begin{array}{l}\text { Not } \\
\text { applicable }\end{array}$ & Not applicable & $\begin{array}{l}\text { Not } \\
\text { applicable }\end{array}$ & $\begin{array}{l}\text { Not } \\
\text { applicable }\end{array}$ & $\begin{array}{l}\text { Not } \\
\text { applicable }\end{array}$ \\
\hline Hungary & $\begin{array}{l}\text { Yes (across } \\
\text { different } \\
\text { laws) }^{\mathrm{a}}\end{array}$ & $\mathrm{No}^{\mathrm{a}}$ & $\mathrm{No}^{\mathrm{a}}$ & $\mathrm{Yes}^{\mathrm{ab}}$ & $\mathrm{No}^{\mathrm{ab}}$ & $\mathrm{Yes}^{\mathrm{ab}}$ & $\mathrm{Yes}^{\mathrm{ab}}$ & $\mathrm{Yes}^{\mathrm{ab}}$ \\
\hline
\end{tabular}


Table 15.4. (Continued)

\begin{tabular}{|c|c|c|c|c|c|c|c|c|}
\hline & $\begin{array}{l}\text { Social Care } \\
\text { Legislation }\end{array}$ & $\begin{array}{c}\text { Special } \\
\text { Provision for } \\
\text { Children with } \\
\text { Complex Care } \\
\text { Needs within } \\
\text { Social Care } \\
\text { Legislation }\end{array}$ & $\begin{array}{l}\text { Measure to Promote the } \\
\text { Welfare of Children with } \\
\text { Complex Care Needs } \\
\text { within Child Protection } \\
\text { Legislation }\end{array}$ & $\begin{array}{l}\text { Financial } \\
\text { Entitlement } \\
\text { in Social } \\
\text { Care Legal } \\
\text { Framework }\end{array}$ & $\begin{array}{c}\text { Home Help OR } \\
\text { Personal Care } \\
\text { Entitlement in } \\
\text { Social Care } \\
\text { Legal } \\
\text { Framework } \\
\text { (HH) (PC) }\end{array}$ & $\begin{array}{c}\text { Family } \\
\text { Support } \\
\text { Entitlement } \\
\text { in Social } \\
\text { Care Legal } \\
\text { Framework }\end{array}$ & $\begin{array}{l}\text { Educational } \\
\text { Entitlement } \\
\text { in Social } \\
\text { Care Legal } \\
\text { Framework }\end{array}$ & $\begin{array}{c}\text { Psychosocial } \\
\text { Entitlement } \\
\text { in Social } \\
\text { Care Legal } \\
\text { Framework }\end{array}$ \\
\hline Iceland & $\mathrm{Yes}^{\mathrm{ab}}$ & $\mathrm{Yes}^{\mathrm{ab}}$ & $*$ & $\mathrm{Yes}^{\mathrm{ab}}$ & $\mathrm{No}^{\mathrm{ab}}$ & $\mathrm{Yes}^{\mathrm{ab}}$ & $\mathrm{Yes}^{\mathrm{ab}}$ & $\mathrm{Yes}^{\mathrm{ab}}$ \\
\hline Ireland & $\begin{array}{l}\text { Yes (across } \\
\text { different } \\
\text { laws) }\end{array}$ & Other $^{\mathrm{ab}}$ & $\mathrm{Yes}^{\mathrm{ab}}$ & $\begin{array}{l}\text { Not } \\
\text { applicable }\end{array}$ & Not applicable & $\begin{array}{l}\text { Not } \\
\text { applicable }\end{array}$ & $\begin{array}{l}\text { Not } \\
\text { applicable }\end{array}$ & $\begin{array}{l}\text { Not } \\
\text { applicable }\end{array}$ \\
\hline Italy & $\mathrm{Yes}^{\mathrm{ab}}$ & $\mathrm{No}^{\mathrm{ab}}$ & $\mathrm{No}^{\mathrm{ab}}$ & $\begin{array}{l}\text { Not } \\
\text { applicable }^{a b}\end{array}$ & $\begin{array}{l}\text { Not } \\
\text { applicable }^{a b}\end{array}$ & $\begin{array}{l}\text { Not } \\
\text { applicable }^{a b}\end{array}$ & $\begin{array}{l}\text { Not } \\
\text { applicable }^{a b}\end{array}$ & $\begin{array}{l}\text { Not } \\
\text { applicable }^{a b}\end{array}$ \\
\hline Latvia & $\mathrm{Yes}^{\mathrm{ab}}$ & $\mathrm{Yes}^{\mathrm{ab}}$ & $\mathrm{Yes}^{\mathrm{ab}}$ & Yes $^{\mathrm{a}}$ & Yes $(\mathrm{HH})^{\mathrm{a}}$ & $\mathrm{No}^{\mathrm{a}}$ & $\mathrm{No}^{\mathrm{a}}$ & Yes $^{\mathrm{a}}$ \\
\hline Lithuania & $\mathrm{Yes}^{\mathrm{ab}}$ & $\mathrm{Yes}^{\mathrm{ab}}$ & $\mathrm{Yes}^{\mathrm{ab}}$ & $\mathrm{Yes}^{\mathrm{ab}}$ & $\mathrm{No}^{\mathrm{ab}}$ & $\mathrm{Yes}^{\mathrm{ab}}$ & $\mathrm{No}^{\mathrm{ab}}$ & $\mathrm{Yes}^{\mathrm{ab}}$ \\
\hline Malta & $*$ & $*$ & $*$ & $*$ & $*$ & $*$ & $*$ & $*$ \\
\hline Netherlands & $\begin{array}{l}\text { Yes (across } \\
\text { different } \\
\text { laws) }\end{array}$ & $\mathrm{No}^{\mathrm{ab}}$ & $\mathrm{No}^{\mathrm{ab}}$ & $\begin{array}{l}\text { Not } \\
\text { applicable }\end{array}$ & Not applicable & $\begin{array}{l}\text { Not } \\
\text { applicable }\end{array}$ & $\begin{array}{l}\text { Not } \\
\text { applicable }\end{array}$ & $\begin{array}{l}\text { Not } \\
\text { applicable }\end{array}$ \\
\hline Norway & $\mathrm{Yes}^{\mathrm{ab}}$ & Other $^{\mathrm{ab}}$ & $\begin{array}{l}\text { Other (the law allows the } \\
\text { social welfare board to } \\
\text { instigate a treatment } \\
\text { order for children with } \\
\text { disabilities or who need } \\
\text { extra help if parents fail } \\
\text { to ensure they receive } \\
\text { necessary services) }^{\text {ab }}\end{array}$ & $\begin{array}{l}\text { Not } \\
\text { applicable }\end{array}$ & Not applicable & $\begin{array}{l}\text { Not } \\
\text { applicable }\end{array}$ & $\begin{array}{l}\text { Not } \\
\text { applicable }\end{array}$ & $\begin{array}{l}\text { Not } \\
\text { applicable }\end{array}$ \\
\hline
\end{tabular}




\begin{tabular}{|c|c|c|c|c|c|c|c|c|}
\hline Poland & $\begin{array}{l}\text { Yes (across } \\
\text { different } \\
\text { laws) }\end{array}$ & Other ${ }^{\mathrm{ab}}$ & $\begin{array}{l}\text { Yes (Recent introduction } \\
\text { of a law called Za życiem } \\
\text { (For Life), which gives } \\
\text { additional support to } \\
\text { parents of children who } \\
\text { have incurable, life- } \\
\text { threatening conditions) }^{\text {a }}\end{array}$ & $\mathrm{Yes}^{\mathrm{ab}}$ & $\mathrm{No}^{\mathrm{ab}}$ & $\mathrm{Yes}^{\mathrm{ab}}$ & $\mathrm{Yes}^{\mathrm{ab}}$ & $\mathrm{Yes}^{\mathrm{ab}}$ \\
\hline Portugal & $\mathrm{Yes}^{\mathrm{ab}}$ & $\mathrm{No}^{\mathrm{ab}}$ & $\mathrm{No}^{\mathrm{ab}}$ & $\begin{array}{l}\text { Not } \\
\text { applicable }\end{array}$ & Not applicable & $\begin{array}{l}\text { Not } \\
\text { applicable }\end{array}$ & $\begin{array}{l}\text { Not } \\
\text { applicable }\end{array}$ & $\begin{array}{l}\text { Not } \\
\text { applicable }\end{array}$ \\
\hline Romania & $\mathrm{Yes}^{\mathrm{ab}}$ & $\mathrm{Yes}^{\mathrm{ab}}$ & $\mathrm{Yes}^{\mathrm{ab}}$ & $\mathrm{Yes}^{\mathrm{ab}}$ & Yes $(\mathrm{HH})^{\mathrm{ab}}$ & $\mathrm{No}^{\mathrm{ab}}$ & $\mathrm{No}^{\mathrm{ab}}$ & $\mathrm{Yes}^{\mathrm{ab}}$ \\
\hline Slovakia & $\mathrm{Yes}^{\mathrm{ab}}$ & $\mathrm{Yes}^{\mathrm{ab}}$ & * & $\mathrm{Yes}^{\mathrm{ab}}$ & Yes $(\mathrm{HH})^{\mathrm{ab}}$ & $\mathrm{No}^{\mathrm{ab}}$ & $\mathrm{Yes}^{\mathrm{ab}}$ & $\mathrm{Yes}^{\mathrm{ab}}$ \\
\hline Spain & $\begin{array}{l}\text { Yes } \\
{\text { (Regional })^{\mathrm{ab}}}^{\text {(Re }}\end{array}$ & $\mathrm{Yes}^{\mathrm{ab}}$ & $\mathrm{No}^{\mathrm{ab}}$ & $\mathrm{No}^{\mathrm{ab}}$ & $\mathrm{No}^{\mathrm{ab}}$ & $\mathrm{No}^{\mathrm{ab}}$ & $\mathrm{No}^{\mathrm{ab}}$ & $\mathrm{Yes}^{\mathrm{ab}}$ \\
\hline Sweden & $\mathrm{Yes}^{\mathrm{ab}}$ & $\mathrm{Yes}^{\mathrm{ab}}$ & $\mathrm{No}^{\mathrm{ab}}$ & $\mathrm{Yes}^{\mathrm{ab}}$ & Yes $(\mathrm{HH})^{\mathrm{ab}}$ & $\mathrm{No}^{\mathrm{ab}}$ & $\mathrm{No}^{\mathrm{ab}}$ & $\mathrm{Yes}^{\mathrm{ab}}$ \\
\hline $\begin{array}{l}\text { UK } \\
\text { (England } \\
\text { (as a part of } \\
\text { the United }\end{array}$ & $\mathrm{Yes}^{\mathrm{ab}}$ & $\mathrm{Yes}^{\mathrm{ab}}$ & $\mathrm{Yes}^{\mathrm{ab}}$ & $\begin{array}{l}\text { Not } \\
\text { applicable }\end{array}$ & Not applicable & $\begin{array}{l}\text { Not } \\
\text { applicable }\end{array}$ & $\begin{array}{l}\text { Not } \\
\text { applicable }\end{array}$ & $\begin{array}{l}\text { Not } \\
\text { applicable }\end{array}$ \\
\hline
\end{tabular}

Notes: ${ }^{\mathrm{a}}$ Country agent response, ${ }^{\mathrm{b}}$ Policy documentation, ${ }^{\mathrm{c}}$ Research literature, ${ }^{\mathrm{d}}$ Other external information sources. ${ }^{*}$ Insufficient information provided. 
18 EU countries. Only six countries stated they had specific objectives regarding the safeguarding of children with complex care needs who have communication or cognitive difficulties.

Having a legal framework is important, but the fact that only half have special recognition for especially vulnerable children and young people, for example those with complex care needs, is potentially worrying. However, it is impossible to know if additional legal protection, which is the case in some countries, makes a difference to the outcomes of the child - because of the lack of comparable and applicable data that describe the physical and social well-being of the child (see Chapters 7 and 8).

\section{Integration of Social Care with Primary Health Care}

Denmark, France, Finland, Hungary, Ireland, Sweden and the UK (Léveillé \& Chamberland, 2010) use the Assessment Framework (AF) (Department of Health, England et al., 2000) as a framework to establish a common language to understand children's needs, thus improving the possibility for effective integrated care This framework is essentially child-centric (see also Chapter 4) and recognises a child's health and social care needs as well as those of parents or carers. Figure 15.2 describes the framework in more detail.

In the MOCHA countries, the integration of care between the services takes the form of formal, legal integration and more informal integration and

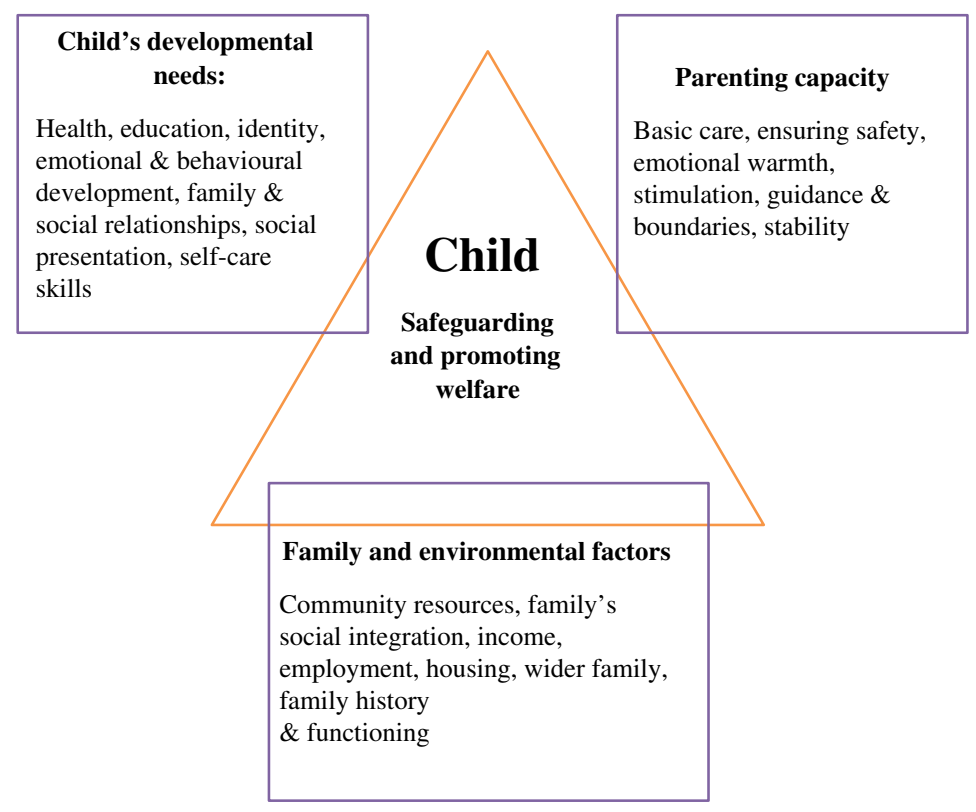

Figure 15.2. Conceptual framework behind the assessment framework. Source; Department of Health, 2000. 
networks between the two services. In $65 \%$ of countries, there were legal or policy frameworks that outline coordination between primary healthcare and social care services, and in 23\% of countries (Croatia, Finland, Italy, Norway, Spain and England (as part of the UK)), they specify a legal and policy framework where both legal and policy documentations are in place to link primary health care and social care. In 19\% of countries, legal frameworks only are described (Czech Republic, Greece, Latvia, Poland and Portugal) and in 19\% of countries (Austria, Bulgaria, Denmark, Estonia and the Netherlands), policy frameworks only are described. In $31 \%$ of countries, neither a legal or policy framework was described to link primary health care and social care. Ireland has a single entity that is responsible for delivering primary and social care, the Health Service Executive - however, in practice, the links between the two remain informal and are not yet fully integrated. Similarly in Finland, it is planned that from 2018, newly identified counties will be in charge of implementing both primary health care and social care (Figure 15.3).

Aside from formal integration of primary care and social care services, there are a number of means by which informal integration takes place in the responding countries, such as co-location of services, coordination through formal networks and informal ad hoc coordination.

\section{Co-location}

Siting primary healthcare and social care professionals together in the primary care setting, on a whole population level is described by two respondents. In Spain, for example, a multidisciplinary primary care team consists of a social worker within a multidisciplinary primary care team, in the same location.



Figure 15.3. Integration between primary health care/social care stipulated in legal/policy framework. 
In some instances, this also occurs in Sweden, but this more often happens in the secondary care setting. In terms of integration of care for all children, colocation of primary healthcare and social care professionals in the primary care setting for children (and mothers) is planned in Bulgaria where maternal and child health centres are being implemented. However, we have interpreted our results on co-location with caution; not least because it is likely there are regional differences in each country, but also that the understanding of "co-location' may be subtly different in separate countries. It is likely that this is more widespread than we have been able to ascertain in this exercise.

\section{Formal Networks}

In Cyprus and Estonia, the country agents described ongoing cooperation between primary healthcare and social care services in the care of children. There are also examples of virtual integration where coordination between primary health care and organisations responsible for providing social care is arranged through networks. This type of integration is reported in Denmark, Estonia, Italy, Norway, Portugal, Romania and England (as part of the UK). To target children with complex care needs, in Ireland, the newly created Children's Disability Network Teams consist of multidisciplinary teams of professionals working together to provide integrated care. In terms of targeted care for children with complex care needs, the Czech Republic primary care physician acts as a formal coordinator of care between the wider health service and social services for children with complex needs; the management of children with complex care needs in this way is part of their training. However, in Denmark, coordinating case workers are used for several target groups, including those with complex care needs, to navigate between social care as well as education, health care and employment.

\section{Informal Networks or Communication}

In some countries, links between primary health care and social care have been created as necessary or as a result of specific circumstances. In Greece, the primary care physician can refer service users to social services, and social services can provide information on health services; in Iceland, the country agent notes that when social counselling is offered, it must be in conjunction with healthcare services. In Germany, paediatricians and social services coordinate to deliver what is called an early-detection exam for all children. In terms of targeted care for children with complex needs, in the absence of formal networks of coordination, Hungary and Croatia described collaboration between services for these children (see Kielthy et al., 2017).

\section{Implementation and Coordination of Social Care and Primary Care Services}

Implementing good care can take the form of many different actions. We asked about the availability of different types of support in a broad sense; often the type and quality of supports provided varied hugely between countries. For example, when asked about the availability of supports for 'parenting skills', 
respondents pointed to provisions ranging from the availability of courses for parents on caring for a child with complex needs, where travel and other course expenses are paid, to online forums where parents can talk online to peers in similar situations.

Implementation of care also implies good coordination of care for the children needing health and social support. The degree to which primary health care and social care are coordinated varies considerably throughout the countries of the study. This coordinated support may be provided through a number of different means:

- coordination of primary health care and social care for the whole population;

- coordination of primary health care and social care for all children; and

- targeted coordinated support, which includes coordination of primary health care and social care, for children with complex needs.

Coordination of both services may be facilitated by the presence of coordinating laws and/or policies that specify how primary health care and social care should be linked, or again, it may be more informal. For children with complex care needs, it is not always primary health care which is a priority when it comes to coordination of care, although the need remains for integrated care. In some cases, the focus of care coordination can be to coordinate care between, for example, secondary hospital care and support in the community. In Denmark, for example, the country agent described how generalised established structures which support cooperation between different sectors and services have been implemented by several municipalities. A coordinating case worker is used for several target groups who receive support from several local government actors; the coordinating case worker navigates between the social area, the employment area and the areas of education and health care.

\section{Flexible Support}

The provision of a care coordinator or case manager for individual cases is recognised as good practice in providing support for children with complex care needs. Alongside the example of coordination of support by a professional, there are examples within MOCHA data of the provision of flexible support which facilitates equity of access. In Poland, for example, access to counselling is offered through the phone or online; the respondent also describes how rehabilitation can be made available at home for those who are unable to attend outpatient treatment centres. In the Czech Republic, the respondent describes how rehabilitation can be made available as a field service providing care in rural areas. On the whole, however, MOCHA data suggested that there is a degree of inequity of access of care coordination and of services in general. Location seemed to be an important factor that affected the availability of specialised rehabilitation care in the community. Reduced access to rehabilitative care was evident from 19\% of responses, cited in Czech Republic, Greece, Hungary, Lithuania and Romania. Additionally, the role played by external organisations 
of various types, particularly not-for-profit organisations, in providing social care is considerable. Access to support in some countries was determined by the resources available to non-profit organisations, or from commercial services in lieu of statutory provided services, meaning that access for some families was dependent on financial resources (see Chapters 5,6 and 9).

Using the tracer condition of acquired brain injury (ABI), the provision of social care support for a child with complex needs showed that a care coordinator or case manager, who can coordinate the required support for the child and family at home or in the community, was present in only $50 \%$ of the countries that responded. In one case, this refers to location-based coordination (Norway). In $38 \%$ of cases, the family was the main coordinator of support most of the time (see also Chapter 10). In Cyprus, no case coordination is available, meaning the family has the responsibility to contact the three government agencies and services that provide social support. In another country, coordination is available in day care centres, but only in certain localities, meaning some families are left unsupported depending on location. The lack of care coordination has the potential to be problematic and challenging for the families, as it relies upon a high level of capability of the parents or guardians. The Polish country agent acknowledged this by saying: 'Activity, competence, awareness, and socio-economic status of parents are crucial in relation to further treatment and development of the child with health problems'. There is concern here because even in countries with a case coordinator role in place, it is possible that many parents are left to manage or coordinate the care for their child. This raises the risk that those parents without the capacity to do so, either because of stress or another reason, are unable to fulfil this role, leaving the child vulnerable - and possibly at risk of needing child protection support. Bulgaria, Finland and England (as a part of the United Kingdom) are notable as they are currently placing emphasis on achieving more comprehensive systems of integration. In Bulgaria, the respondent notes that a National Program for the Improvement of Maternal and Child Health was implemented in 2014, partly as a result of a lack of integrated medical and social approaches to serve children with chronic disease or disability. A number of measures to link social care services to primary health care have been identified and seem to reflect good practice. One measure is the creation of Centres for Maternal and Child Health; services will be provided by doctors specialising in obstetrics, gynaecology and paediatrics, as well as nurses, midwives, social workers and psychologists, both in the centre and in the family home. In Finland, greater integration will be achieved through the creation of autonomous counties which will be responsible for both primary healthcare and social care provision (at present, they are under control of the municipal level) from 2018. In England (as a part of the United Kingdom) meanwhile, the emphasis is on increasing the effectiveness of coordination of care through virtual integration with the creation of networks of clinical commissioning groups. A less extensive recent change in Romania has seen a law brought into effect to specify the manner in which the social and health sectors should coordinate care for children and adolescents with disabilities/and or special educational needs. 


\section{Child Protection}

There is some evidence to suggest that the safeguarding needs of children with complex care needs are not being fulfilled (European Union Agency for Fundamental Rights, 2015a), even though we know that disabled children with complex care needs are three to four times more likely to be victims of violence, neglect and abuse than other children (Jones et al., 2012; Stalker \& McArthur, 2012; Sullivan, 2009; Sullivan \& Knutson, 2000) For more information, see Kielthy et al. (2017). All countries in the MOCHA study reported the presence of a child protection framework. However, the FRA reports that a main law for child protection is present in only 18 countries. No MOCHA respondent described a change in policy or legal framework prompted by failings in the child protection system by exposing a child with complex care needs or disability to risk, although, in Chapter 17, child abuse is identified as a cultural phenomenon that has been a stimulus for policy discussions in more than one country.

\section{Access and Participation}

Participation in a child's care from all parties, including from the child, is important for quality social care. An additional important element is good accessibility of services. In Denmark, for example, all children considered to be in need of special support are assessed for social care needs, in what is termed the Children's Specialist Examination. It is based on a holistic approach, as it includes parameters such as development and behaviour, family relationships, school, health, leisure time activities and friendships. The examination is used to assess whether there is a need for special support for the child and family and what kind of support is necessary.

\section{Funding and Equity of Access}

The delivery of social support is achieved via a complex array of organisational and funding structures across the MOCHA countries. We did not seek to establish the level of funding provided for these services (see also Chapters 7 and 9), but it seems reasonable to assume that there will be variations in the level of spending. It is thus challenging to establish how easy it is for a child and family to access support and whether funding or insurance coverage is sufficient to meet the need or if there exists some form of 'rationing' or prioritisation based on level of need, which limits a patient's access to care. What is evident from the Country Agent data is that most countries have an element of regional variation in the delivery of social care. For example, living in a rural area can disadvantage children with complex care needs and their families (something that is also reflected in a 2015 OECD report on integrated social services for vulnerable groups). It is important that existing policies must be facilitated in practice throughout each country in order to ensure equity of access.

\section{Information Provision for Support to Parents}

The provision of support services for parents/guardians may help to bridge the gap between those who find it easier to participate in the caregiving process and 
those who find it more difficult. An initiative in Norway which aims to meet the informational and support needs of parents of a child with a complex care needs is a weekend-long parenting course entitled Hva med oss? or What about us? The purpose is to strengthen relationships and family life, and provide families with the chance to swap experiences, to reflect and to celebrate. It is also noted that for parents of a child with complex care needs, meeting parents in a similar situation can be very beneficial. The Estonian Social Insurance Board is composed of 13 units and 17 customer service points around Estonia, and in addition, the Social Insurance Board has an informative website where important information and materials about activities, subunits and social insurance news are posted. The objective is to make sure that individuals anywhere in the country can find out exactly which customer service point or employee can address their concern and the legal basis for the granting of entitlement to state benefits.

\section{Equity of Access to Supports}

As reported previously, several country agencies reported that there were regional variations in some services; a disparity in availability of care is clearly apparent in rural areas compared to urban areas in many countries. A number of respondents reported that access to supports can vary depending on the funding priorities of the locality, municipality or region. This is effectively a determinant of access to services.

\section{Compensation for Costs Associated with Care}

In Denmark and Finland, the country agents outlined the availability of financial compensation for travel and accommodation for parents of a child with a complex care need. In Denmark, compensation may also be provided for additional costs, such as overnight stays at a hospital location, or for special diets that children may need, and travel expenses. Other examples of financial compensation include expenses paid to parents for taking parenting courses relevant to children with complex care needs. In Finland, compensation may be provided for travel and overnight accommodation costs to help with a child and an accompanying person's travel costs if the child needs to travel in order to undergo examination and receive treatment.

\section{Summary}

We have shown that primary care is more than the traditional medical and nursing health care services. Pharmacy, Dental services and Social care services perform or have the potential to provide essential roles for children and young people. Needs from pharmacy, dentistry and social care are varied and interwoven with needs from each other and from the healthcare system. Yet, because this inter-connectivity is not sufficiently recognised in the EU and EEA countries, there is a need for improvement of coordination and with the need for these services to focus more fully on children and young people. 


\section{Pharmacy}

Pharmacies are very much used, but their value to children and young people seems not to be sufficiently recognised in EU and EEA countries. The relationship between community pharmacies and primary care services needs to be recognised and strengthened in order to substantially improve access and treatment for children's illnesses, especially for those children who are managing chronic conditions. Pharmacists are an extremely important part of primary care in the broadest sense, and the advice of a highly trained pharmacist is invaluable. Not least because medicines for children are often only available off-label, or not available in the correct dose. This skilled activity includes giving clear and accurate information about doses, how to take the medication and any interactions with other medications (Pharmaceutical Group of the European Union (PGEU), 2012). Pharmacies can potentially provide a much greater role in terms of improving self-management and well-being of generally healthy children. This could be further strengthened by the development of stronger links between pharmacists and other primary care professionals, such as physicians, nurses and allied health professionals to provide a truly comprehensive service to children and young people.

\section{Dentistry}

Preventive dentistry is available throughout the EU and EEA, but there are few targeted incentives to ensure that children receive the service. The presence of free service alone seems to be relied on as an incentive by many countries, even though this has not been shown to be effective in reducing inequalities. Services to children who are disabled or who have particular needs vary in their accessibility and availability across the EU and EEA.

\section{Social Care Services}

Mapping social care services to children with complex healthcare needs across all EU countries has presented significant challenges due to the different cultural contexts. In addition, the role played by multiple organisations of various types in the provision of social care throughout Europe is considerable. This represents fragmentation of social care provision and must present a challenge for coordination between primary health care and social care as state and non-state actors must cooperate. This also makes it more difficult to map the availability and accessibility of social care services within each country. It is also clear that, for many children, it is their parents or carers who will be responsible for making sure their social care needs are met. In many countries, parents may have to navigate various statutory and/or external organisations in order to access the additional supports that they and their child require.

Arrangements for coordination between primary health care and social care are common to a number of countries. As noted, some countries are investing significant policy and organisational development in further integrating health 
and social care systems. In Finland, real integration is prioritised with the creation of a model where systems will be more fully integrated by coming under the responsibility of one organisation. It should be kept in mind; however, Lewis, Rosen, Goodwin, and Dixon (2010) note that full organisational integration is not necessarily optimal and 'it may be that a care user's needs are better served through less organisational integration and more opportunity for choice and personalisation of care across a range of alternative providers that is well coordinated' (2010, p. 12). Leutz is of a similar opinion for a different reason; he asserts that coordination may be a better strategy when striving to meet the needs of the whole population (1999).

\section{References}

Alexander, D., \& Blair, M. (2018). Children and young people's use of pharmacy in primary care. Retrieved from http://www.childhealthservicemodels.eu/wp-content/ uploads/member-files/MOCHA-Pharmacy-in-primary-care-for-children-Confidential-Draft-May-2018.pdf

Alma, M., Mahtani, V., Palant, A., Klůzová Kráčmarová, L., \& Prinjha, S. (2017). Report on patient experiences of primary care in 5 DIPEx countries. Retrieved from http://www.childhealthservicemodels.eu/wp-content/uploads/Patient-experiences-of-primary-care-in-five-countries.pdf

B.A.H. (2016). Jeder Dritter möchte mehr Beratung bei der Medikamenteneinnahme. Retrieved from www.bah-bonn.de/index.php? $\mathrm{ID}=$ dumpFile\&t $=\mathrm{f} \& \mathrm{f}=9083 \&$ token=1a6b85418431b046266eac6327bfdd81b7ca79b0

Blair, M., \& Menon, A. (2018). Community pharmacy use by children across Europe: A narrative literature review. Pharmacy, 6, 51. doi:10.3390/pharmacy60 20051

Department of Health. (2000). Framework for the assessment of the needs of children and their families. London: The Stationery Office. Retrieved from http://webarchive.nationalarchives.gov.uk/20130123203811/ http://www.dh.gov.uk/en/Publicationsandstatistics/Publications/PublicationsPolicyAndGuidance/DH_4003256

European Union Agency for Fundamental Rights. (2015a). Violence against children with disabilities: Legislation, policies and programmes in the $E U$. Retrieved from http://fra.europa.eu/en/publication/2015/children-disabilities-violence

European Union Agency for Fundamental Rights. (2015b). Mapping child protection systems in the EU. Retrieved from http://fra.europa.eu/en/publications-andresources/data-and-maps/comparative-data/child-protection

Gill, P., Goldacre, M. J., Mant, D., Heneghan, C., Thomson, A., Seagroatt, V., \& Harnden, A. (2013). Increase in emergency admissions to hospital for children aged under 15 in England, 1999-2010: National database analysis. Archieves of Disease in Childhood, 98, 328-334. doi:10.1136/archdischild-2012-302383

Gobina, I., Villberg, J., Villerusa, A., Välimaa, R., Tynjälä, J., Ottova-Jordan, V., ... Holstein, B. E. (2014). Self-reported recurrent pain and medicine use behaviours among 15-year olds: Results from the international study. European Journal of Pain, 19(1), doi:10.1002/ejp.524/pdf

Irish Pharmacy Union. (2015). Review of the Irish community pharmacy sector 2013/ 14: Sustainability in a changing environment. Retrieved from https://docplayer.net/ 
17926664-Review-of-the-irish-community-pharmacy-sector-2013-14-sustainability-ina-changing-environment.html

Jones, L., Bellis, M. A., Wood, S., Hughes, K., McCoy, E., Eckley, L., ... Officer, A. (2012). Prevalence and risk of violence against children with disabilities: A systematic review and meta-analysis of observational studies. Lancet, 380(9845), 899-907. doi:10.1016/S0140-6736(12)60692-8

Kielthy, P., Warters, A., Brenner, M., \& McHugh, R. (2017). Final report on models of children's social care support across the EU and the relationship with primary health care. Retrieved from http://www.childhealthservicemodels.eu/publications/ deliverables/

Lara Montero, A., van Duijn, S., Zonneveld, N., Minkman, M., \& Nies, H. (2016). Integrated social services in Europe. European Social Network. Retrieved from www.esn-eu.org/raw.php?page $=$ files\&id $=1910$

Leutz, W. N. (1999). Five laws for integrating medical and social services: Lessons from the United States and the United Kingdom. Milbank Quarterly, 77(1), $77-110$.

Léveillé, S., \& Chamberland, C. (2010). Toward a general model for child welfare and protection services: A meta-evaluation of international experiences regarding the adoption of the framework for the assessment of children in need and their families (FACNF). Children and Youth Services Review, 32(7), 929-944. doi:10.1016/j.childyouth.2010.03.009

Lewis, R., Rosen, R., Goodwin, N., \& Dixon, J. (2010). Where next for integrated care organisations in the English NHS? London: The Nuffield Trust. Retrieved from https://www.nuffieldtrust.org.uk/research/where-next-for-integrated-careorganisations-in-the-english-nhs

Marchant, R., Lefevre, M., Jones, M., Luckock, B. (2007). Knowledge review: Necessary stuff - The social care needs of children with complex health care needs and their families. Project Report, 18. Social Care Institute for Excellence (Scie), London. Retrieved from https://www.scie.org.uk/publications/knowledgereviews/ kr18.asp

Pharmaceutical Group of the European Union. (2012). European community pharmacy blueprint. Retrieved from https://pgeu.eu/en/policy/19-the-european-community-pharmacy-blueprint.html

Pharmaceutical Society of Ireland (PSI). (2016). Future pharmacy practice in Ireland PSI Irish pharmacy regulator. Retrieved from https://www.thepsi.ie/Libraries/ Pharmacy_Practice/PSI_Future_Pharmacy_Practice_in_Ireland.sflb.ashx

Platform for Better Oral Health. (2012). The state of oral health in Europe. Retrieved from http://www.oralhealthplatform.eu/our-work/the-state-of-oral-health-ineurope/

Siponen, S. (2014). Children's health, self-care and the use of self-medication - A population-based study in Finland. University of Eastern Finland. Retrieved from http://epublications.uef.fi/pub/urn_isbn_978-952-61-1418-7/urn_isbn_978-952-611418-7.pdf

Stalker, K., \& McArthur, K. (2012). Child abuse, child protection and disabled children: A review of recent research. Child Abuse Review, 21(1), 24-40. doi:10.1002/ car.1154

Sullivan, P. M. (2009). Violence exposure among children with disabilities. Clinical Child and Family Psychology Review, 12(2), 196-216. 
Sullivan, P. M., \& Knutson, J. F. (2000). Maltreatment and disabilities: A population-based epidemiological study. Child Abuse \& Neglect, 24(10), $1257-1273$.

Waszyk-Nowaczyk, M., \& Simon, M. (2009). Pharmaceutical care as an area of pharmacist-physician collaboration. Farmacja Polska, 65(10), 713-716.

Ylinen, S., Hämeen-Anttila, K., Sepponen, K., Lindblad, A. K., \& Ahonen, R. (2010). The use of prescription medicines and self-medication among children A population-based study in Finland. Pharmacoepidemiology and Drug Safety, 19(10), 1000-1008. doi:10.1002/pds.1963. Retrieved from https://www.ncbi.nlm. nih.gov/pubmed/20712023 